\title{
TRANSFORMING MASS PRODUCTION CONTACT CENTRES USING APPROACHES FROM MANUFACTURING
}

\author{
Marisa K. Smith ${ }^{1}$, Peter D. Ball ${ }^{2}$, Umit S. Bititci ${ }^{1}$ and Robert van der Meer ${ }^{1}$ \\ ${ }^{1}$ Strathclyde Institute for Operations Management, University of Strathclyde, James Weir \\ Building, 75 Montrose Street, Glasgow, G1 1XJ, UK. \\ Tel: +44(0) 1415482588 \\ E-mail: $\underline{\text { m.k.smith@strath.ac.uk; }}$ u.s.bititci@strath.ac.uk; robert.van-der-meer@strath.ac.uk \\ ${ }^{2}$ Manufacturing Department, Cranfield University, Building 50, Cranfield, Bedfordshire, MK43 \\ OAL, UK. Tel +441234750111 ext 5657 \\ E-mail: p.d.ball@cranfield.ac.uk
}

\section{BIOGRAPHIES}

\section{Dr Marisa K. Smith}

Marisa is a research fellow with the Strathclyde Institute for Operations Management. Her research concentrates on contact centre operations, in particular how to influence innovation and change in contact centres. As part of her $\mathrm{PhD}$ work she has carried out case studies with a number of different contact centres within the UK, to understand how their characteristics impact on their capacity to innovate. She is also interested in how lean principles are applied to the service operations context. 


\section{Dr Peter D. Ball}

Dr Peter Ball is Senior Lecturer in Manufacturing Operations at Cranfield University. His research interests lie in the area of design and operation of systems and supply chains and how models and modelling techniques support this. Peter has collaborated with many large companies as well as SMEs on research and technology transfer projects. These projects saw the adoption of new and standard manufacturing and business processes and tools as part of the companies' operations. He has deployed supply chain diagnostic tools as a Supply Chain Counselor for the development agency, Scottish Enterprise. He was an investigator on Strathclyde's Centre for Business Process Outsourcing (CBPO) and PI \& CI on many TCS/KTP programmes focused on business process improvement. He has published papers in the area of simulation, outsourcing, supply chain management and e-business. He is a chartered member of the IET (Institution of Engineering and Technology), a member of the IOM (Institute of Operations Management) and a fellow of the HEA (Higher Education Academy). He is active within both IET (professional review assessor and interviewer) and IOM (events chair).

\section{Prof. Umit S. Bititci}

Umit is a Professor at the University of Strathclyde. As a management professional, consultant and academic he has more than 20 years of experience working with a wide spectrum of UK, European and Asian companies on business transformation and improvement projects. He has been responsible for a number of European and UK funded research and development programmes. 
To date Umit has published three edited books and over 100 papers in international journals and conferences.

\section{Dr Robert van der Meer}

Dr Robert B. van der Meer gained his Bachelor's degree in Economics and Business Administration from the University of Amsterdam, his Master's degree in Economics from the London School of Economics, and his Ph.D. from the University of Strathclyde. His main research interests are in management science, operations management and strategy, and the economics of organisation, management and strategy.

Robert is Director of Education, Strathclyde Institute of Operations Management, and Director of Undergraduate Studies (Honours Year), Department of Management Science, University of Strathclyde.

Robert is a member of the Operational Research Society (UK). He was Chairman of the OR Group of Scotland (2001-5), Director of the Operational Research Society (2004-6) and has been Regional Member for Scotland on the General Council of the Operational Research Society since 2004. He is also a member of the European Operations Management Association and the Production and Operations Management Association (USA), and is a Fellow of the Higher Education Association. Robert has worked with organisations in a wide range of industries including electronics (IBM, Motorola, etc.), spirits (Allied Distillers, The Edrington Group, etc.), clothing (Playtex, Levi Strauss, Coats Thread) - and in the public sector (in particular, NHS 
Scotland). He has also acted as an Independent Expert advising the GMB Union on a number of occasions. 


\section{ABSTRACT}

\section{Purpose}

The purpose of this paper is to identify theories from manufacturing which can be applied to alleviate current issues within contact centre organisations. As contact centres currently adopt a mass production approach to customer service, this paper aims to examine the key issues currently facing contact centres and investigate how manufacturing has overcome some of its issues with the mass production approach.

\section{Design/methodology/approach}

The research employs a qualitative case study approach using a cross section of different types of contact centre to identify the current issues with contact centres. Interview and direct observation are the chosen methods for data collection and the data is analysed using a series of deductive and emergent codes.

\section{Findings}

From empirically investigating the issues that contact centres are currently facing it would imply that they have the same issues as manufacturing historically faced. Therefore, we can conclude that if manufacturing can develop from an industry founded on scientific management principles then so can the contact centre industry.

\section{Research limitations/implications}

The findings of this research provide a useful starting point to discuss the ability of theories developed in manufacturing to be adapted into the contact centre context. This research is a 
starting point for further work into the applicability of manufacturing theories into the contact centre environment and as such it is deliberately discussed at a high level of abstraction.

\section{Practical implications}

Many of the techniques employed in contact centres originate from manufacturing's past but little of the research focuses on how contact centres can learn from manufacturing's future therefore this paper has practical implications in identifying which concepts can be transferred from manufacturing to contact centres.

\section{Originality/value}

The value of this paper is that it looks to the future of contact centre operations and discusses which techniques can be transferred from manufacturing to alleviate some of the current issues with contact centres.

\section{Keywords}

Contact centres, operations management, case studies

\section{Paper type}

Research paper 


\section{INTRODUCTION}

Many organisations use contact centres for interacting with their customers and are often the front line customer facing function of many organisations. Although contact centres are efficient in cost saving terms and in that they allow customers access to organisations at times, and through contact methods, that are suitable to the them, there are issues with their effectiveness. The use of contact centres is not just apparent in the private sector but their use is also prevalent in the public and third sector organisations (i.e. charities) (DTI, 2004). Historically, contact centres were initially set up in order to take advantage of economies of scale and utilise the developments in information and communication technology (ICT), the primary motivation for this was cost rationalisation (Anton, 2000). This focus on cost reduction has led to contact centres adopting a mass production approach to service provision. Consequently contact centres receive a grim representation in literature with some authors regarding them as akin to the sweatshops and factories of the past (e.g. Fernie and Metcalf, 1998). They are regularly depicted as unattractive places to work which provide substandard levels of service to disgruntled customers and are often referred to as 'an assembly line in the head'(Taylor and Bain, 1999).

Many of the techniques employed in contact centres originate from manufacturing's past with some contact centre scholars drawing parallels with factory environments and Taylorism (Bain and Taylor, 2000; Bain et al., 2002; Batt and Moynihan, 2002; Calvert, 2004) but little of the existing research focuses on how contact centres can learn from manufacturing's future. In order to overcome this limitation in existing research, the research presented in this paper discusses 
current issues with the contact centre operating model and examines if these can be overcome by learning from developments in manufacturing.

Figure 1 shows the conceptual framework that is driving this research.

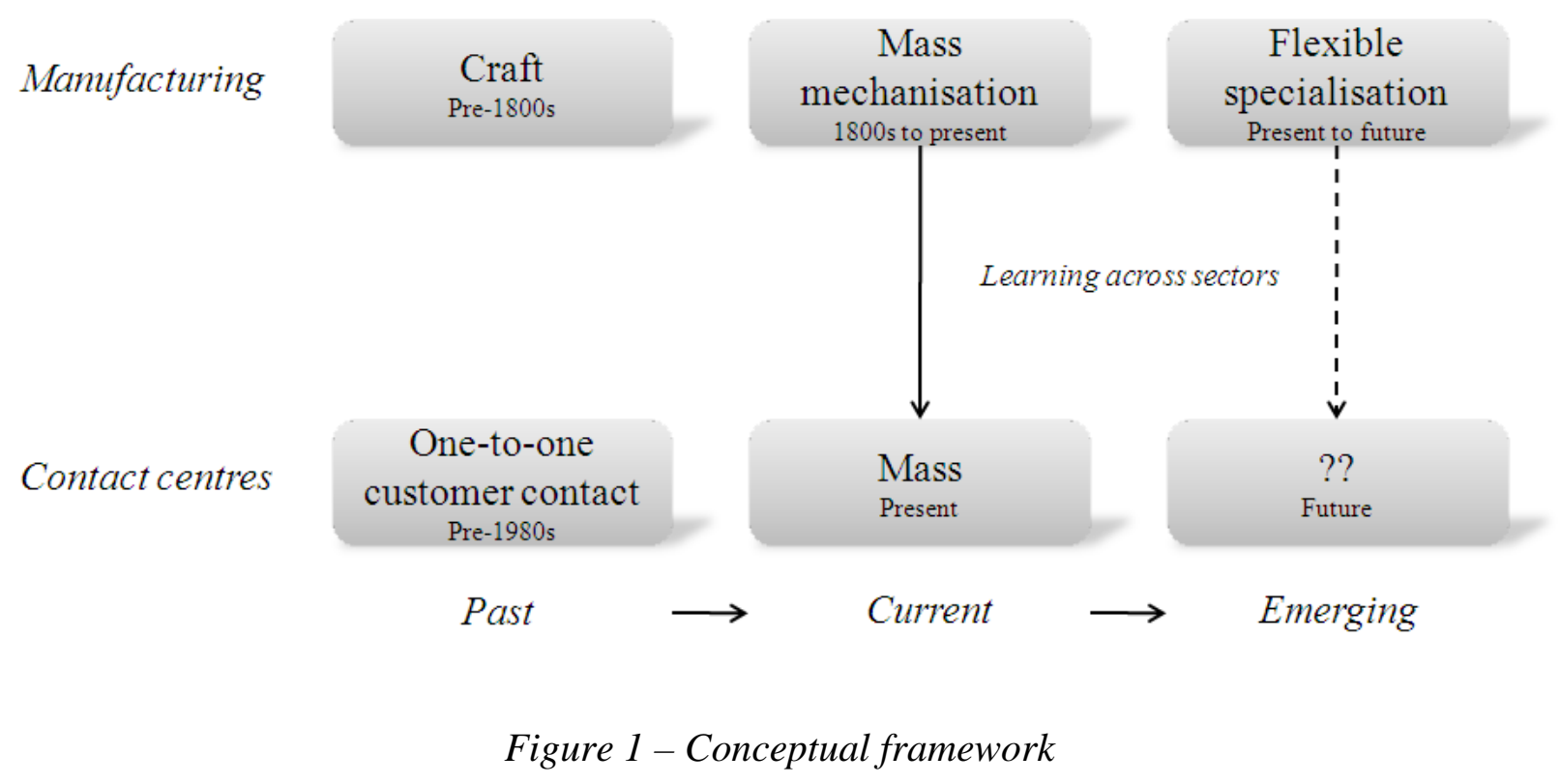

As Figure 1 shows there has been organisational learning occurring across the organisational divide between manufacturing and contact centres, primarily between the mass approaches, but this research is interested in understanding if the organisational learning from manufacturing can still be used for developing the emerging contact centre model. Therefore, the research question (RQ) driving this research is:

$R Q:$ Can the mass production model of contact centres be improved by adopting methods that have moved manufacturing from mass to modern manufacturing? Or do they diverge and follow another path? 
Figure 1 shows the development of manufacturing as three distinct phases, these are the craft phase, the mass manufacturing phase and the modern phase (Mair, 1993). In the craft phase products were made by skilled craftsmen who focused on low volume production on a small scale where the focus was on satisfying the customer and the quality of the product. The advent of mechanisation and the industrial revolution meant that manufacturing was considered on a large scale in a mass manufacturing model. In this production model products were manufactured in high volumes but with a low variety of the types of products. A number of key theories were behind the development of this production model such as, the introduction of scientific management principles, the use of standardised and interchangeable parts and the moving assembly line. The main focus of this production model is productivity improvement. The third phase, the modern phase, the focus has shifted due to highly fragmented markets, the reduction in product lifecycles and the demand from consumers for more choice in the products they are purchasing. This modern manufacturing phase is characterised by concepts such as flexible specialisation (Piore and Sabel, 1984), lean production (Womack et al., 1990), mass customisation (Pine et al., 1993) and agile manufacturing (Kidd, 1994).

Although modern manufacturing techniques have their foundations in the work of scientific management and mass production techniques (Schmenner, 2001) the sector has improved through the adoption of operations management techniques to allow increases in productivity, product quality and employee satisfaction. The dominance of the mass production contact centre model shows that contact centres lag behind developments in manufacturing operations management. This could be due to contact centres being a relatively young concept, with the 
business model of contact centres only being widely used since the 1980 's, meaning that the industry is currently approximately 30 years old. Nevertheless, the industry is still adopting management techniques that have their roots in 1800's in manufacturing.

In order to understand if contact centres can overcome their issues by learning from manufacturing, the current operational issues facing contact centres need to be examined and compared against what techniques, theories and methodologies manufacturing utilises.

\section{APPROACH}

The methodological approach that this study takes is an exploratory case study approach. Case studies allow complex relationships to be understood and also have the benefit of the research being carried out in the natural setting of the organisation, meaning that the situation is not artificially created. In theory this should result in observations that are a true representation of the case company that is under investigation (Yin, 2003). This is important when examining issues concerning a specific type of organisation. In order to get a representative view of the contact centre industry a selection of different types of contact centre were selected for the study to reflect the wide and varied nature of the contact centre industry. Table 1 illustrates the selection of large and small size centres as well as centres that deal with simple services and ones the service complex enquires. 
Table 1 - Composition of case companies

\begin{tabular}{|c|c|c|c|c|c|c|}
\hline $\begin{array}{l}\text { Case } \\
\text { Company }\end{array}$ & $\begin{array}{l}\text { Direction of } \\
\text { contact }\end{array}$ & Customers & Nature of services & Size & Ownership & Sector \\
\hline Centre A & Inbound & Consumer & $\begin{array}{l}\text { Complex customer } \\
\text { services }\end{array}$ & Small & Outsourced & Public \\
\hline Centre B & Inbound & Consumer & $\begin{array}{l}\text { Simple customer } \\
\text { services }\end{array}$ & Large & In-house & Public \\
\hline Centre C & $\begin{array}{l}\text { Inbound \& } \\
\text { Outbound }\end{array}$ & Business & $\begin{array}{l}\text { Complex technical } \\
\text { helpdesk }\end{array}$ & Large & In-house & Private \\
\hline Centre D & Outbound & Consumer & $\begin{array}{l}\text { Simple customer } \\
\text { services }\end{array}$ & Small & In-house & Public \\
\hline Centre E & $\begin{array}{l}\text { Inbound \& } \\
\text { Outbound }\end{array}$ & $\begin{array}{l}\text { Consumer \& } \\
\text { Business }\end{array}$ & $\begin{array}{l}\text { Complex technical } \\
\text { helpdesk } \\
\text { Simple sales }\end{array}$ & Large & In-house & Private \\
\hline Centre F & Inbound & $\begin{array}{l}\text { Consumer \& } \\
\text { Business }\end{array}$ & $\begin{array}{l}\text { Simple customer } \\
\text { services }\end{array}$ & Large & In-house & Private \\
\hline Centre G & Inbound & Consumer & $\begin{array}{l}\text { Simple customer } \\
\text { service }\end{array}$ & Large & In-house & Private \\
\hline Centre H & Inbound & Consumer & $\begin{array}{l}\text { Simple customer } \\
\text { service }\end{array}$ & Large & In-house & Private \\
\hline
\end{tabular}

Given the exploratory nature of this research, interview and direct observation were the chosen methods for data collection. The methods provided commonality of data collection across the cases with flexibility to explore issues that were important in the particular context. Notes were taken during the interviews along with audio recordings. These notes were combined with notes from direct observation of contact centre activity and compiled into case study notes.

The purpose of this research is to identify common themes across the cases and not on identifying the differences between the cases. The analysis used a coding technique where the data was coded in NVivo using a combination of deductive codes and emergent codes that developed as the analysis was performed. The deductive codes were taken from Tompkins et al. 
(1996) areas of description which they used to characterise each phase of manufacturing development. The Tompkins et al. (1996) categories were selected to ease the comparison between contact centres and manufacturing. As the primary data collected in this study is only from contact centres and not from manufacturing, the comparison to manufacturing will be based on manufacturing literature.

The deductive codes are:

- Management and organisation

- People development

- Operations capability and automation

- Operations focus

- Improvement approaches

- External relationships and interaction

In cases where the deductive codes could not be used to properly classify the data then an emergent code was created. In the case of this research the only emergent code that developed was 'performance management'. For example if the interviewee said "agents get [pressure] to make sure they are meeting their productivity targets" then this would be coded as performance management. This type of analysis followed an iterative process of coding to ensure that the codes were robust and that data was coded correctly.

The next stage in the analysis was to identify common themes and characteristics within each of the codes. The themes that were common across four or more cases were identified as important 
issues that have implication on the operations management of contact centres. Table 2 shows the findings from the contact centre case studies.

Table 2 - Findings from contact centre cases

\begin{tabular}{|c|c|c|}
\hline Area & Issues identified from case data & Case where evident \\
\hline $\begin{array}{l}\text { Performance } \\
\text { management }\end{array}$ & $\begin{array}{l}\text { - Individual agent volume based metrics } \\
\text { - Productivity based targets }\end{array}$ & $\begin{array}{l}\mathrm{B}, \mathrm{C}, \mathrm{D}, \mathrm{E}, \mathrm{G}, \mathrm{H} \\
\mathrm{B}, \mathrm{C}, \mathrm{D}, \mathrm{E}, \mathrm{F}, \mathrm{G}, \mathrm{H}\end{array}$ \\
\hline $\begin{array}{l}\text { Management } \\
\text { and } \\
\text { organisation }\end{array}$ & $\begin{array}{l}\text { - Electronic surveillance by management } \\
\text { - Employee involvement team } \\
\text { - Teams are used to stimulate competition between } \\
\text { areas of the centre }\end{array}$ & $\begin{array}{l}\text { A, B, C, E, F, G } \\
\text { A, B, E, G, H } \\
\text { B, E, F, G }\end{array}$ \\
\hline $\begin{array}{l}\text { People } \\
\text { development }\end{array}$ & $\begin{array}{l}\text { - Training is mainly focused on the usage of IT } \\
\text { systems and processes } \\
\text { - Agents are not given time off phone for other } \\
\text { activities } \\
\text { - Job design is restricted with no or little job rotation } \\
\text { or enrichment }\end{array}$ & $\begin{array}{l}\text { A, B, C, E, F, G, H } \\
B, C, E, F \\
B, C, D, E, F, G\end{array}$ \\
\hline $\begin{array}{l}\text { Operations } \\
\text { capability and } \\
\text { automation }\end{array}$ & $\begin{array}{l}\text { - Service is based on a mass production approach } \\
\text { - Processes are governed by the IT system } \\
\text { - Automation is used for contact avoidance }\end{array}$ & $\begin{array}{l}\text { B, E, F, G } \\
\text { A, B, C, E, F, G, H } \\
\text { A, B, F, G }\end{array}$ \\
\hline $\begin{array}{l}\text { Operations } \\
\text { focus }\end{array}$ & $\begin{array}{l}\text { - Focus is on processing numbers and not on resolving } \\
\text { customers needs } \\
\text { - Focus is agent utilisation }\end{array}$ & $\begin{array}{l}\text { B, E, F, G } \\
A, B, C, D, E, F, G, H\end{array}$ \\
\hline $\begin{array}{l}\text { Improvement } \\
\text { approaches }\end{array}$ & $\begin{array}{l}\text { - There is little continuous improvement and no focus } \\
\text { on innovation } \\
\text { - Improvement focus is on cost reduction and } \\
\text { increasing productivity }\end{array}$ & $\begin{array}{l}\text { A, B, C, D, E, F, G, H } \\
\text { A, B, C, E, F, G }\end{array}$ \\
\hline $\begin{array}{l}\text { External } \\
\text { relationships } \\
\text { and interaction }\end{array}$ & $\begin{array}{l}\text { - Adverse relationship with customers and employees } \\
\text { - Limited contact with external organisations }\end{array}$ & $\begin{array}{l}\mathrm{B}, \mathrm{E}, \mathrm{F}, \mathrm{G} \\
\mathrm{B}, \mathrm{C}, \mathrm{D}, \mathrm{E}, \mathrm{F}, \mathrm{G}\end{array}$ \\
\hline
\end{tabular}

In order to understand if these issues can be addressed by developments adopted from manufacturing it is necessary to identify how manufacturing has developed in each of the operational areas. Table 3 is developed by Tompkins et al. (1996) and shows the development 
from traditional manufacturing management characteristics to current and future thinking in manufacturing. 
Table 3 - Stages of progression from traditional manufacturing to contemporary manufacturing (Tompkins et al., 1996)

\begin{tabular}{|c|c|c|c|c|}
\hline & Past & Present & Present & Future \\
\hline Area & Traditional Manufacturing & $\begin{array}{l}\text { Uncoordinated Incremental } \\
\text { Improvements }\end{array}$ & $\begin{array}{l}\text { Focused and Coordinated } \\
\text { Product and Process } \\
\text { Improvements }\end{array}$ & $\begin{array}{l}\text { Contemporary } \\
\text { Manufacturing }\end{array}$ \\
\hline $\begin{array}{l}\text { Management and } \\
\text { organisation }\end{array}$ & $\begin{array}{l}\text { - Hierarchical } \\
\text { - Impersonal management } \\
\text { - Functional focus }\end{array}$ & $\begin{array}{l}\text { - Participative management } \\
\text { - Fewer management layers } \\
\text { - More open communication }\end{array}$ & $\begin{array}{l}\text { - Minimum management layers } \\
\text { - Focused layouts } \\
\text { - Employee involvement teams } \\
\text { - Work cells }\end{array}$ & $\begin{array}{l}\text { - Self-managed teams } \\
\text { - Paperless business }\end{array}$ \\
\hline People development & - Minimum training & $\begin{array}{l}\text { - Extensive education and training } \\
\text { begins }\end{array}$ & $\begin{array}{l}\text { - Cross-trained workforce with job } \\
\text { rotation }\end{array}$ & \\
\hline $\begin{array}{l}\text { Operations capability and } \\
\text { automation }\end{array}$ & $\begin{array}{l}\text { - } \text { Mass production, inflexible } \\
\text { processes } \\
\text { - Long production runs } \\
\text { - } \text { Long lead times } \\
\end{array}$ & & $\begin{array}{l}\text { - Flexible automation } \\
\text { - Smaller lots }\end{array}$ & $\begin{array}{l}\text { - Low inventories, small lots } \\
\text { - Error-free work }\end{array}$ \\
\hline Operations focus & $\begin{array}{l}\text { - Focus on full capital and labour } \\
\text { utilisation }\end{array}$ & & - Quicker response to customer & $\begin{array}{l}\text { - Short lead-times, quick response } \\
\text { - } 100 \% \text { on time delivery } \\
\text { - Produce to customers needs } \\
\text { - Customer service excellence } \\
\end{array}$ \\
\hline Improvement approaches & & $\begin{array}{l}\text { - "Waste elimination" focus } \\
\text { - Awareness of total cost of } \\
\text { quality } \\
\text { - Management committed to the } \\
\text { quality improvement process }\end{array}$ & $\begin{array}{l}\text { - Detailed process studies } \\
\text { - Statistical control } \\
\text { - Preventative maintenance }\end{array}$ & - Constant innovation \\
\hline $\begin{array}{l}\text { External relationships and } \\
\text { interaction }\end{array}$ & $\begin{array}{l}\text { - Adversarial relationships with } \\
\text { suppliers, customers, and } \\
\text { employees }\end{array}$ & $\begin{array}{l}\text { - Developing supplier } \\
\text { relationships }\end{array}$ & $\begin{array}{l}\text { - Just-in-time purchasing and } \\
\text { operations }\end{array}$ & - Customer/supplier partnerships \\
\hline
\end{tabular}


This table will be used as a tool to direct the comparison between the findings from the contact centre case studies and the best practice in manufacturing. As was discussed previously the only emergent code developing from the data was 'performance management' and the discussion starts with this area.

\section{DISCUSSION}

The discussion takes each area in turn and discusses the issues in contact centres and compares how manufacturing has addressed these issues.

\section{Performance management}

The issues identified from the contact centre cases concerning performance management are focused on individual agent volume based metrics and productivity based targets. Performance management in contact centres has received much attention from academics primarily focusing on how to implement service quality measures into the contact centre environment (Gilmore, 2001; Bain et al., 2002; Clarkson and Hodgkinson, 2005). While some scholars working in the manufacturing field have started to look at the performance measurement issue in contact centres from a more balanced view (e.g. Marr and Neely, 2004). 
Almost all of the cases in this study had targets and metrics based on call handling levels to which each individual agent had to make their targets. In case F agents' names were displayed in the work area with their current performance and adherence to the targets presented for all the team to see. The thinking behind this is to identify the agents who are not performing to the targets.

This metrics driven performance culture is also echoed in cases A and E. In case E one team leader said that "agents are heavily measured-performance improvement plans put in place if agents are not meeting their targets - team leaders have the responsibility to manage this problem." Again this quote shows that performance is based on agents meeting their targets. In this case the targets were based on the number of customers serviced in a day. While day based targets were common across the cases there was evidence from case $\mathrm{F}$ which showed that some contact centres used tally sheets to measure how many customers were dealt with in an hour period. In case F agents used a template sheet which said "answering 8 per hour makes our customers happy" on the top of the sheet and the agents had to tick a box when they finished a call.

The other issue with performance measures was that meeting the predefined targets often lead to a reward. One agent in Case A said that "there are other incentive and rewards schemes ... but these are linked to performance, and high performing employees can become agents of the month." The use of rewards and performance related bonuses is common across many of the cases in this study. 
Performance management is a major field in manufacturing research and to overcome the issues faced by the mass production approach, where quantity was the key metric, manufacturing scholars have developed a more holistic approach to performance. The balanced scorecard (Kaplan and Norton, 1996) and the performance prism (Neely et al., 2001) have been major developments in the performance management of manufacturing (although both approaches have a wider scope than manufacturing) therefore contact centres could attempt to have a more balanced approach to performance, focusing on quality and employees as well as productivity measures.

From investigating the contact centre literature it would seem that both performance management and contact centre scholars are working towards the more balanced view of performance management that is apparent in manufacturing. However, the empirical evidence collected in this study implies that the focus is still on productivity measures.

\section{Management and organisation}

The main issues identified from the cases concerning management and organisation focused on the use of electronic surveillance by management. All cases, apart from case D who were considering the implementation of call listening equipment at the time of the study, used electronic recordings to monitor the calls and the way the agents dealt with the customer. This technology is used without the knowledge of the agent, they are 
unaware of what calls their manager will listen to. This is to ensure adherence to quality levels or any scripts that might be used to deal with customer.

While call listening and monitoring was common throughout the cases, there were examples (primarily case F) of the electronic control where agents' breaks were scheduled by the computer system and the agent was monitored on their adherence to the system. This is also true of the management knowing when agents are free to take calls, agents do not have control over the volume of calls they handle, this is also controlled by the computer system which will route calls to an agent as soon as they are finished the other call. This is demonstrated by an agent from case $\mathrm{G}$ who said "we've got like a productivity target [of] $83 \%$ so you've got to ... to take calls on the phone ... so if you've got a customer who you're doing something in their file but you don't want to keep them on the phone because you don't want them ending up irate ... if you let them got you can't take another call ... because you'd be in the [first] person's file ... and then all you'll hear is "get on the phone, get on the phone" but you can't because you're doing something." This quote shows that the agent is still trying to do work for the customer but as their manager can see that they are not taking calls they pressure the agent to take more calls.

Some research has taken place into the effects this remote electronic surveillance has on contact centre agents (Garson, 1988; Bain and Taylor, 2000). The Bain and Taylor (2000) study actually looks at how agents are finding ways to resist the 'electronic panopticon', which is how they describe this type of surveillance. This electronic 
monitoring and remote control can result in a culture where the agents feel that they are not trusted by management. While manufacturing did not have electronic surveillance, in the same way that contact centre do, it did suffer from staff feeling untrustworthy by management. Hay (2002) has shown that the dynamic of trust develops in manufacturing organisations as initiatives such as just-in-time manufacture and team based working are implemented. Therefore, contact centres have the opportunity to learn from the advances in operator/management relationship development from manufacturing. There is however still an issue with team based working in contact centres.

Table 3, we shows that future manufacturing will have self-managed teams; while the contact centres in this study did use teams most of them used teams to stimulate competition between areas of the centre. In cases B, F and $\mathrm{G}$ teams were given names (for example, in case $\mathrm{G}$ the teams are named after football team and they have a league table to show how the teams are performing hour by hour) the teams are normally performing the same tasks and so are in direct competition with each other. In case $\mathrm{E}$ the team leader said "teams do compete against each other - incentives are put in place every quarter from top management for team leaders to compete and this goes down to the agent level - reward could be a day off or a day out with the company paying." Teams in contact centres are often down to organising agents into manageable numbers and nothing to do with the interaction between team members.

The nature of contact centre work means that agents are working on their own on a oneto-one basis with the customer, which means interaction with other team members can be 
limited for example; a team leader from case B said "It is hard for agents to interact with each other this is due to the nature of the job".

If contact centres were to move to self-managed teams the concept of 'team' would need to be addressed in the contact centre context as well as the issue with trust. This might result in the whole idea of a contact centre job being redesigned and the service model being reconsidered.

Tompkins et al. (1996) in Table 3 say that employee involvement teams are part of focused and coordinated product and process improvements in current manufacturing. From the contact centre case studies it can be witnessed that many of the cases did have some level of employee involvement or participation groups. For example, case A has a staff representation group "we have a group called the *** group - staff representation and managers go into it and meet fortnightly - put forward ideas, concerns and suggestions about the business as a whole" in this case the company have this group so that management can stop any issues escalating to major problems. Where as in case B they have a staff ideas scheme which encourages agents to get involved in improvement activities, the improvement manager said that "staff ideas scheme works because the staff want to be involved in something more exciting than their day-to-day jobs."

Contact centres often place a lot of emphasis on staff wellbeing such as in case A, B, G and $\mathrm{H}$ which have free fruit or food on certain days of the week or month, this is due to the high rates of attrition in the industry (Wallace et al., 2001). Some researchers are investigating the effect of contact centre work on employee wellbeing (Holman, 2002), 
sickness (Taylor et al., 2003) and stress levels (Grandey et al., 2004; Holman, 2004). It would seem from the evidence in both the contact centre literature and from the evidence from the primary data that contact centres have a well developed attitude to employee involvement and participation.

\section{People development}

One of the issues identified from the contact centre cases was that training is mainly focused on the usage of IT systems and processes and is normally 'on the job' training as can be seen from the training manager from case B who said that "agents received 2 days training with the company (not on phones), 1 week 'buddy' training and then 5 weeks and 3 days on the job training”. The same training manager also highlights the performance culture, discussed previously, existing in contact centres as they say that "training is making direct links with performance data - to show that training has an impact on contact centre performance”. This highlights that the role of training in contact centres is again to boost contact centre performance rather than for people development. The trust and productivity issues again are seen in case B by the training manager highlighting that "team leaders thought training was just time off telephones."

One of the reasons for the limited focus on training in contact centres could be that management are reluctant to give agents time off the phones for other activities. This is demonstrated by the team leader from case E saying that " a lot of guys on the frontline wouldn't have time to do the projects as they get a lot of hassle to make sure they are 
meeting their productivity targets" this relates to the time they are available to take calls, so once again the nature of the job restricts agents from being involved in projects and training that could help them develop.

This leads on to the third people development issue in contact centres which is that job design is restricted with no or little job rotation or enrichment. In Table 3 Tompkins et al. (1996) highlight that manufacturing currently has cross-trained workforces with job rotation which is achieved through extensive education and training. However, at present contact centre work is still based on specialisation of tasks, with only case A attempting any type of job rotation. However case A has had issues in implementing this new form of working as this quote demonstrates "we try to get to a true blended environment gone through cross-skilling to get to this environment - blending has been put in but agents have had problems with it, they have become demoralised and we have lost agents due to it - so we have listened to our employees and stopped this process of blending now have chunks of work where agents will do phones for 2 hours and then do 2 hours of e-mail - new agents will be put into place they won't know any different environment." While job rotation and enrichment could provide substantial benefits for contact centres there will be issues of culture and it would require a substantial change in the processes and systems of the contact centre. 


\section{Operations capability and automation}

One of the issues with operations capability in contact centres is that their processes are governed by the IT system and due to the flexible nature of IT these processes can be changed rapidly. For example in case $\mathrm{G}$ processes can be changed in a matter of hours but as one of the business information managers said "we can make changes to the process very quickly but sometimes you don't know what changes other people have made, so the process becomes very messy." This is very different to manufacturing where any changes in the production process would often require substantial effort from a variety of people. In this case contact centres could take a more structured approach to process changes and development so that the process is working at the optimal level and that everyone knows how the end-to-end process operates.

Flexible automation has allowed greater flexibility in manufacturing (Adler, 1988), due to the dynamic nature of contact centre environments there is a need for more flexibility in the automation used. Case $\mathrm{A}$ in this study did have highly flexible automation in that their recorded messages were change depending on the demand created by the wider organisation which was rather dynamic. The technology development manager discussed their Interactive Voice Response (IVR) technology at case B also said that "IVR's are used for high volume services and are provided by an external provider. High volume drives IVR's and automation - we have to mange customers expectations. There is lots of information through the internet - to encourage customers to self-serve". The issue with the future of contact centres is that self-service (i.e. automation which is aimed at call avoidance) can often drive more complex problems which customers will contact the 
centre with. Therefore, the automated systems need to be responsive to changes prompted by customers' needs as well as the external environment.

\section{Operations focus}

The issue identified from the primary data is that contact centres have a focus on processing numbers, through high levels of agent utilisation, and not on resolving customers' needs. Some of the cases did say they considered quality of the calls as well as quantity as seen by the team leader for case $\mathrm{C}$ "we do have scripting in this area of the contact centre but we are interested in quality as well as the quantity of the calls." However, as was discussed previously many of the cases for example B, E, F and G still have call handling targets and metrics displayed in the centres.

The current operations focus of contact centres is to reduce call handling times, volumes and maximise the throughput of customers this is similar to manufacturing's past where the reduction of cycle times and throughput was the focus. However, manufacturing has paved the way in quality management (Oakland, 2003) and has made the operational focus on quality, cost and delivery to the customer. While the operational focus of contact centres is primarily concerned with efficiency there is evidence from the empirical data that there is a move to a customer service focus.

Although it has been found that efficiency is the main operational drive behind contact centres there are still issues with customers being held in queues for a long time before being able to talk to a contact centre employee. These long queue times result in 
customers abandoning their place in the queue and make the contact centre, and therefore the organisation, inaccessible to the customer. This has been a major issue for case $\mathrm{F}$ who at the time of this study were having queue times of over an hour for customers to talk to an agent. By taking lessons learnt from manufacturing there needs to be quicker responses to the customers needs and this can be achieved through job rotation and enhanced system and process design by utilising ICT to enhance the customer experience rather than simply improve productivity.

\section{Improvement approaches}

One of the key issues surrounding improvement approaches in contact centres is that there is little continuous improvement and no focus on innovation. When there is an improvement focus it is on cost reduction and increasing productivity. A manager at case E said that "we have a lot of business improvement teams - green belts, black belts - to save money and drive productivity" it should be noted that the manager was talking about management level employees and not agents, however from this quote it can be seen that the drive is again focused on productivity. It is a key theme to the operational ethos of contact centres.

At the moment improvement approaches in contact centres are focused around processes and from this study it was found that much of the improvement schemes were put in place for employee involvement rather than business improvement. Again this is due to the nature of the job as one agent demonstrated from case B 'the 'buzz' days introduced 
by management have fell flat as the agents didn't have time off the phone in order to enjoy the activities." This was also true in cases $\mathrm{E}$ and $\mathrm{F}$ where agents were not allowed to leave the phones so they could not be involved in any of the improvement teams, however in case $\mathrm{F}$ the employees who were not on the phones were able to participate in the projects.

Tompkins et al. (1996) in Table 3 shows that manufacturing has a management committed to the quality improvement process. From the empirical evidence collected it would seem that contact centre management still have a bias towards productivity focused improvements. Therefore, a systems thinking (Checkland, 1999) and a culture of continuous improvement needs to be installed within contact centres before co-ordinated improvement approaches will be evident in contact centres. Continuous improvement is a key theme in the development of manufacturing operations, with many studies being carried out into it (e.g. Bessant and Francis, 1999; Boer et al., 2000). It has been shown to improve employee morale, boost productivity and develop new methods of working. However, the nature of the job would have to be reconsidered in order for continuous improvement to be truly adopted in contact centres.

Tompkins et al. (1996) identifies that 'waste elimination' is a key stage in the development of manufacturing and the pioneering work on lean manufacturing (Ohno,1988), looks at reducing wastes within manufacturing operations and has continuous improvement in the foundations of its principles. Although lean has been extensively studied and implemented in the manufacturing sector there is now a growing 
field in service operations and the contact centre industry has been no exception (Piercy and Rich, 2008). There is a number of the contact centres included in this study, namely cases $\mathrm{G}$ and $\mathrm{H}$, embarking on lean improvement programmes at the time of this research. But the evidence from these cases is that lean is being embraced for its cost reducing outcome and not its process improvement possibilities.

\section{External relationships and interaction}

At the moment many contact centres do not have a positive relationship with their customers or the wider organisation, this could be due to the fact that contact centres are often at the periphery of the wider organisation. As part of the systems thinking (Checkland, 1999) approach organisations consider all the interactions and collaborations that they are involved with.

Manufacturing is at the forefront of the supply chain management field but again services are also looking at service supply chain (Ellran et al., 2004) but at the moment contact centres do not think about integration or collaboration in the same way which manufacturing firms do. However, in this study there are some exceptions to this and some actively benchmark with other contact centres and the industry body (the customer contact association-CCA), case A is a good example of the type of external relationships and interaction that contact centres have as the operations manager said "we work with external organisations - have a lot of external people come in such as our clients - we host events for the CCA". 
Table 4 summarises the findings of this research, it can be seen that many of the issues occurring in current contact centre operations have also been issues for manufacturing in the past. Therefore, there are a number of manufacturing theories that can be further extended into the contact centre context to alleviate some of the issues identified in the empirical field at this point in time.

Table 4 - Theories from manufacturing which can apply to contact centre development

\begin{tabular}{|c|c|c|}
\hline Area & Issues identified from case data & $\begin{array}{l}\text { Theories from manufacturing with } \\
\text { potential for use in contact centres }\end{array}$ \\
\hline $\begin{array}{l}\text { Performance } \\
\text { management }\end{array}$ & $\begin{array}{l}\text { - Individual agent volume based metrics } \\
\text { - Productivity based targets }\end{array}$ & $\begin{array}{l}\text { - Balanced performance measures } \\
\text { incorporating quality measures } \\
\text { - Awareness of total cost of quality }\end{array}$ \\
\hline $\begin{array}{l}\text { Management } \\
\text { and } \\
\text { organisation }\end{array}$ & $\begin{array}{l}\text { - Electronic surveillance by management } \\
\text { - Employee involvement team } \\
\text { - Teams are used to stimulate competition } \\
\text { between areas of the centre }\end{array}$ & $\begin{array}{l}\text { - Participative management } \\
\text { - More open communication } \\
\text { - Self managed teams }\end{array}$ \\
\hline $\begin{array}{l}\text { People } \\
\text { development }\end{array}$ & $\begin{array}{l}\text { - Training is mainly focused on the usage of } \\
\text { - IT systems and processes } \\
\text { Agents are not given time off phone for } \\
\text { other activities } \\
\text { - Job design is restricted with no or little job } \\
\text { rotation or enrichment }\end{array}$ & $\begin{array}{l}\text { - Extensive training and education } \\
\text { - Cross-trained workforce with job } \\
\text { rotation }\end{array}$ \\
\hline $\begin{array}{l}\text { Operations } \\
\text { capability and } \\
\text { automation }\end{array}$ & $\begin{array}{l}\text { - Service is based on a mass production } \\
\text { approach } \\
\text { - Processes are governed by the IT system } \\
\text { - Automation is used for contact avoidance }\end{array}$ & - Flexible automation \\
\hline $\begin{array}{l}\text { Operations } \\
\text { focus }\end{array}$ & $\begin{array}{l}\text { - Focus is on processing numbers and not on } \\
\text { resolving customers needs } \\
\text { - Focus is agent utilisation }\end{array}$ & $\begin{array}{l}\text { - Management committed to the } \\
\text { quality improvement process } \\
\text { - Customer service excellence }\end{array}$ \\
\hline $\begin{array}{l}\text { Improvement } \\
\text { approaches }\end{array}$ & $\begin{array}{l}\text { - There is little continuous improvement and } \\
\text { no focus on innovation } \\
\text { - Improvement focus is on cost reduction } \\
\text { and increasing productivity }\end{array}$ & $\begin{array}{l}\text { - "Waste elimination" focus } \\
\text { - Constant innovation } \\
\text { - Customer service excellence }\end{array}$ \\
\hline $\begin{array}{l}\text { External } \\
\text { relationships } \\
\text { and interaction }\end{array}$ & $\begin{array}{l}\text { - Adverse relationship with customers and } \\
\text { employees } \\
\text { - Limited contact with external } \\
\text { organisations }\end{array}$ & 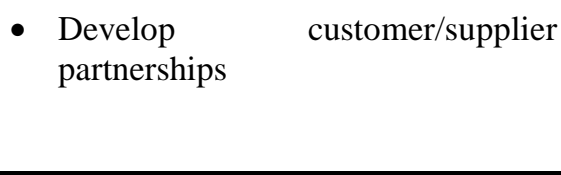 \\
\hline
\end{tabular}




\section{CONCLUSIONS}

The aim of this research was to understand if contact centres can continue to base their future on lessons learnt from manufacturing, with the research question driving this study RQ: Can the mass production model of contact centres be improved by adopting methods that have moved manufacturing from mass to modern manufacturing? Or do they diverge and follow another path?

From empirically investigating the issues that contact centres are currently facing it would imply that they have the same issues as manufacturing historically faced. Therefore, we can conclude that if manufacturing can develop from an industry founded on scientific management principles then so can the contact centre industry. This means that contact centres can be improved by adopting the methods that have moved manufacturing from mass to modern.

The findings of this research provide a useful starting point to discuss the ability of theories developed in manufacturing to be adapted into the contact centre context. This research is a starting point for further work into the applicability of manufacturing theories into the contact centre environment and as such it is deliberately discussed at a high level of abstraction. Further work will investigate detailed aspects of each of the issues and manufacturing theories touched on in this paper. 


\section{REFERENCES}

Adler, P. S. (1988). Managing Flexible Automation. California Management Review, 30(3), 34-57.

Anton, J. (2000). The past, present and future of customer access centers. International Journal of Service Industry Management, 11(2), 120-130.

Bain, P., and Taylor, P. (2000). Entrapped by the 'electronic panopticon' Worker resistance in the call centre. New Technology, Work and Employment, 15(1), 2-18.

Bain, P., Watson, A., Mulvey, G., Taylor, P., and Gall, G. (2002). Taylorism, targets and quality by call centre management. New Technology, Work and Employment, 17(3), 170.

Batt, R., and Moynihan, L. (2002). The viability of alternative call centre production models. Human Resource Management Journal, 12(4), 14.

Calvert, N. (2004). Gower Handbook of Call and Contact Centre Management. Aldershot: Gower Publishing Limited.

Checkland, P. (1999). Systems Thinking. In W. Currie, and Gallaries, B. (Ed.), Rethinking Management Information Systems: An Interdisciplinary Perspective. Oxford: Oxford University Press.

Clarkson, G., and Hodgkinson, G. (2005). Sensemaking on the Front Line: The Key Implications for Call Centre Performance: Advanced Institute of Management Research.

Dti (2004). The UK Contact centre Industry : A Study.

Ellram, L. M., Tate, W. L., and Billington, C. (2004). Understanding and Managing the Services Supply Chain. The Journal of Supply Chain Management, 40(4), 17-32. 
Fernie, S., and Metcalf, D. (1998). (Not) Hanging on the Telephone : Payment Systems in the New Sweatshops. London: Centre for Economic Change : London School of Economics.

Garson, B. (1988). The Electronic Sweatshop : How Computers are Transforming the Office of the Future into the Factory of the Past. New York: Simon \& Schuster.

Gilmore, A. (2001). Call centre management: is service quality a priority? Managing Service Quality, 11(3), 153-159.

Hay, A. (2002). TRUST AND ORGANISATIONAL CHANGE: AN EXPERIENCE FROM MANUFACTURING. SA Journal of Industrial Psychology, 28(4), 40-44.

Holman, D. (2002). Employee weelbeing in call centres. Human Resource Management Journal, 12(4), 35.

Holman, D. (2003). Phoning in sick? An overview of employee stress in call centres. Leadership and Organization Development Journal, 24(3), 123-130.

Kaplan, R. S., and Norton, D. P. (1996). Linking the balanced scorecard to strategy. Californian Management Review, 03(1), 53-79.

Kidd , P. T. (1994). Agile Manufacturing: Forging New Frontiers: Addison-Wesley. Mair, G. (1993). Mastering Manufacturing: Palgrave Macmillan.

Marr, B., and Neely, A. (2004). Managing and Measuring for Value: The Case of Call Centre Performance. Measuring Business Excellence, 8(4), 55-62.

Neely, A., Adams, C., and Crowe, P. (2001). The Performance Prism in Practice. Measuring Business Excellence, 5(2), 6-12.

Oakland, J. (2003). Total Quality Management: Text with Cases (3rd ed.). Oxford: Butterworth-Heinemann.

Ohno, T. (1988). Toyota Production System: Beyond Large-Scale Production. Portland: Productivity Press. 
Piercy, N., and Rich, N. (2008). Lean transformation in the pure service environment: the case of the call service centre. International Journal of Operations \& Production Management, 29(1), 54-76.

Pine, B. J. I., and Davis, S. (1993). Mass Customization: Harvard Business School Press.

Piore, M. J., and Sabel, C. F. (1984). The Second Industrial Divide: Prospects for Prosperity: Basic Books.

Schmenner, R. W. (2001). History of Technology, Manufacturing, and the Industrial Revolution: A Rejoinder. Production and Operations Management, 10(1), 103-106.

Taylor, P., and Bain, P. (1999). 'An Assembly Line in the Head' : Work and Employee Relations in the Call Centre. Industrial Relations Journal, 30(2), 101-117.

Taylor, P., Baldry, C., Bain, P., and Ellis, V. (2003). `A Unique Working Environment': Health, Sickness and Absence Management in UK Call Centres Work, employment and society, 17(3), 435-458.

Tompkins, J. A., White, J.A., Bozer, Y.A., Frazelle, E.H., Tanchoco, J.M.A., and Trevino, J. (1996). Facilities Planning (2nd ed.). New York, NY: John Wiley \& Sons.

Wallace, C., Eagleson, G., and Waldersee, R. (2000). The sacrificial HR strategy in call centres. International Journal of Service Industry Management, 2(174-184).

Womack, J. P., Jones, D. T., and Roos, D. (1990). The Machine that Changed the World: The Story of Lean Production: Harper Perennial.

Yin, R. K. (2003). Case Study Research: Design and Methods (3rd ed.). London: Sage Publications. 